\title{
Study of Some Serological Markers (Hbs Ag, Anti-Hbs and Ant- Hbc Igm) for Detection of Occult Hepatitis B Virus Infection Among Blood Donors in Diyala Province
}

\author{
Ibtihal Hameed Mohsin Al-Ezzi *and Ansam Dawod Salman ** \\ * Assistant Lecturer in Diyala University, Collage of Science, Department of Biology \\ ** Lecturer in Diyala University, Collage of Science, Department of Biology
}

\begin{abstract}
The present study was conducted in Diyala province for the period from 15/ 1 / 2016 to 15 / 12/2016, In the Central Blood Bank in the public Health Laboratory in Diyala. The aim of the study was to detection the rate of Occult Hepatitis B virus infection among blood donors using ELISA test to screening different serological markers (HBs Ag, anti- HBs and anti- HBc IgM). The study included; 200 apparently healthy blood donors were attended central blood bank in Diyala. 183 of blood donors were males and 17 were females. The age range was 18 years to 58 years. The results showed that the rate of HBs Ag among blood donors (4.5\%), and the rate of anti-HBs was (10\%), while the rate of anti-HBc IgM was (4\%). The present results revealed that the rate of anti-HBs was (9.4\%) among HBs Ag negative blood donors, and the anti-HBc IgM (4.1\%). While the rate of positive serological markers was $13.6 \%$. The present study showed that there was relationship between the HBs Ag positivity rate and anti-HBs against anti-HBc IgM do not have.
\end{abstract}

\section{Introduction}

The genus Hepatitis B virus is a member of the family Hepadnaviridae. It is a double stranded circular DNA virus composed of an outer envelope containing hepatitis B surface antigen (HBsAg) and an inner nucleocapsid consisting of hepatitis $\mathrm{B}$ envelope antigen $(\mathrm{HBeAg})$ and hepatitis $\mathrm{B}$ core antigen $(\mathrm{HBcAg})$. Corresponding antibodies to each of these antigens are Hepatitis B surface antibody (anti-HBs or HBs Ab), Hepatitis B envelope antibody (anti-HBe) and hepatitis B core IgM and IgG antibody (anti-HBc) ${ }^{(1,2)}$.

Hepatitis B virus (HBV) infection is a global, public health of importance. It occurs worldwide and up to two billion people, approximately $30 \%$ of the world's populations have been infected globally. Of this, 300400 million people are chronically infected, approximating to about $5 \%$ of the world's population at risk of developing the complications of chronic HBV infection. Death resulting from HBV yearly, stand at about 500000 to 102 million worldwide. Most of these due to squealed of chronic HBV infection such as cirrhosis, liver failure and hepatocellular carcinoma $(\mathrm{HCC})^{(3,4, \text { and } 5)}$.

The modes of transmission of hepatitis B exit. HBsAg can be detected in saliva, nasopharyngeal washings, semen, menstrual fluid, and vaginal secretions as well as in blood. Transmission from carriers to close contacts by the oral route or by sexual or other intimate exposure occurs. There is strong evidence of transmission from persons with subclinical case and carriers of $\mathrm{HBs} \mathrm{Ag}$ to homosexual and heterosexual longterm partners. As well as the transmission of $\mathrm{HBV}$ may be due to blood contamination during blood transfusion. Transmission by fecal-oral route has not been documented ${ }^{(6)}$.

The serological markers of HBV are $\mathrm{HBsAg}$, anti-HBs, $\mathrm{HBcAg}$, anti- $\mathrm{HBc}$ (IgM and $\mathrm{IgG}$ ), $\mathrm{HBeAg}$, anti-HBe and HBV DNA; these are important as they can be used in the diagnosis of the in the diagnosis of the infection and to determine the severity of the infection. HBsAg can be detected in high levels in serum during acute or chronic HBV infection. The presence of HBsAg indicates that the person is infectious. The presence of anti- HBs is generally interpreted as indicating recovery and immunity from HBV infection. Anti-HBs also develop in a person who has been successfully vaccinated against HBV. Anti-HBc appears at the onset of symptoms in acute $\mathrm{HB}$ and persists for life. The presence of anti-HBc indicates previous or ongoing infection with $\mathrm{HBV}$ in an undefined time frame ${ }^{(3,7, \text { and } 8)}$.

Detection of HBsAg in blood is a diagnostic marker for infection with HBV and in blood banks screening for HBsAg is carried out routinely to detect HBV infection. Occult HBV infection is defined as the presence of HBV-DNA in blood or liver tissues in patients negative for HBsAg but who may or may not be positive for HBV antibodies ${ }^{(9,10)}$.

However, some HBsAg negative individuals with positive anti-HBc and/or positive for anti-HBs continue to be positive for HBV DNA. Due to limitations in current blood screening practices in developing countries, donation by such individuals is a potential source of HBV transmission to the recipients ${ }^{(11,12) .}$ In this study was designed to detection of some serological markers (HBsAg, anti- HBs and anti-HBc IgM) of occult HBV infection in blood donors. 
Study groups:

\section{Materials And Methods}

The present study was conducted in Diyala province for the period from 15/ 1 / 2016 to 15 / 12/ 2016. It included; 200 apparently healthy blood donors were attended central blood bank in Diyala. 183of blood donors were males and 17 were females. The age range was 18 years to 58 years.

\section{Collection of serum specimens:}

From each individual in this study, $5 \mathrm{ml}$ of blood was drawn by vein puncture using disposable syringes. The blood was placed in plastic disposable tubes; it was left to stand at room temperature $\left(20-25 \mathrm{C}^{\circ}\right)$ to allow it to clot, then the sera was separated by centrifugation 10000 r.p.m for 5 minutes and stored at $-20{ }^{\circ} \mathrm{C}$ till examination. The specimens were transferred to the Virology Unit / Public Health Laboratory in Baquba for detection of $\mathrm{HBsAg}$, anti-HBs and anti-HBc IgM in serum specimens by ELISA test. All sera and reagents were allowed to stand at room temperature before use in the test.

\section{Detection of serological markers: \\ HBsAg (serum) ELISA test:}

This test was performed using commercially available kit (DRG.ELISA). Reactive results were indicated by the absorbance reading of 0.03 and above, while the non-reactive results were indicated by the absorbance reading less than 0.03 .

\section{Anti-HBs (serum) ELISA test:}

This test was performed using commercially available kit (DRG.ELISA). Reactive results were indicated by the absorbance reading of 0.1 and above, while the non-reactive results were indicated by the absorbance reading less than 0.1 .

\section{Anti-HBc IgM (serum) ELISA test:}

This test was performed using commercially available kit (DRG.ELISA). Reactive results were indicated by the absorbance reading of 0.2 and above, while the non-reactive results were indicated by the absorbance reading less than 0.2 .

\section{Study groups:}

\section{Results}

Twenty hundred of apparently healthy blood donors were in clouded in this study. The mean age of blood donors were $(32.49) \pm 3.6$ years. The age rang was 18 to 58 year. $183(91.5 \%)$ of blood donors were males and $17(8.5 \%)$ were females. $98(49 \%)$ of blood donors were reside in urban areas, while $102(51 \%)$ were reside in rural areas. Table (1) showed the demographic data of blood donors.

Table (1): Demographic data of blood donors

\begin{tabular}{|l|l|}
\hline Demographic data & No. $(\%)$ \\
\hline Gender & $183(91.5)$ \\
Male & $17(8.5)$ \\
Female & $200(100.0)$ \\
Total & \\
\hline Age groups (years) & $65(32.5)$ \\
$<30$ & $89(44.5)$ \\
$30-39$ & $46(23)$ \\
$40+$ & $200(100.0)$ \\
Total & \\
\hline Residence & $98(49)$ \\
Urban & $102(51)$ \\
Rural & $200(100.0)$ \\
Total & \\
\hline
\end{tabular}

Using the ELISA test for detection of different HBV serological markers (HBsAg, anti-HBs and anti$\mathrm{HBc} \operatorname{IgM}$ ) in serum of blood donors, the results in table (2) showed that $9(4.5 \%)$ of blood donors were positive for HBs Ag, while were 20 (10\%) of blood donors positive for anti-HBs. However, 8 (4\%) from donors given positive results for anti-HBc IgM. And the sum of the $37(18.5 \%)$ of blood donors were as positive for different HBV serological markers. 
Table (2): The rate of Hepatitis B virus serological markers among study groups

\begin{tabular}{|l|l|}
\hline Viral markers & No. positive (\%) \\
\hline HBs Ag & $9(4.5 \%)$ \\
\hline Anti-HBs & $20(10 \%)$ \\
\hline Anti-HBc IgM & $8(4 \%)$ \\
\hline Total & $37(18.5 \%)$ \\
\hline
\end{tabular}

$\mathrm{N}=200$

Table (3) demonstrated positive rate of viral markers for HBV among blood donors were negative for HBs $\mathrm{Ag}$, it is found results $18(9.4 \%)$ from donors were positive to anti-HBs of virus, while gave $8(4.1 \%)$ positive results for anti-HBc IgM. The sum of 26 (13.5\%) of blood donors were positive for different HBV serological markers.

Table (3): Positive rate of $\mathrm{HBV}$ among blood donors negative for $\mathrm{HBs} \mathrm{Ag}$

\begin{tabular}{|l|l|}
\hline Viral markers & No. positive (\%) \\
\hline Anti-HBs & $18(9.4)$ \\
\hline Anti-HBc IgM & $8(4.1)$ \\
\hline Total & $26(13.5)$ \\
\hline
\end{tabular}

Table (4) showed the relationship between positive rate of HBs Ag for HBV and anti-HBs against the anti-HBc IgM. The results revealed that the positive donors for $\mathrm{HBs} \mathrm{Ag}$ and anti-HBs were not positive for anti-HBc IgM.

Table (4): Positive rate of HBs Ag and anti-HBs for HBV against the anti-HBc IgM

\begin{tabular}{|l|l|l|}
\hline \multirow{2}{*}{ Positive viral markers } & Anti-HBc IgM \\
\cline { 2 - 3 } & Negative $\mathbf{n = 1 9 2}$ & Positive n=8 \\
\cline { 2 - 3 } & No. $(\boldsymbol{\%})$ & No. $(\%)$ \\
\hline HBs Ag & $9(4.6)$ & $0(0.0)$ \\
\hline Anti- HBs & $20(10.4)$ & $0(0.0)$ \\
\hline
\end{tabular}

In table (5) reported the relationship between positive of $\mathrm{HBs} \mathrm{Ag}$ of $\mathrm{HBV}$ and anti-HBc IgM against the anti-HBs, it is found 2(10\%) from donors were positive for HBs Ag and anti- HBs. On the other hand, any of the donors who are positive for anti-HBc IgM was not positive for the anti- HBs.

Table (5): Positive rate of HBs Ag and anti-HBc IgM for HBV against the anti-HBs

\begin{tabular}{|l|l|l|}
\hline \multirow{3}{*}{ Positive viral markers } & Anti-HBs \\
\cline { 2 - 3 } & Negative $\mathbf{n = 1 8 0}$ & Positive $\mathbf{n = 2 0}$ \\
\cline { 2 - 3 } & No. $(\boldsymbol{\%})$ & No. $(\%)$ \\
\hline $\mathrm{HBs} \mathrm{Ag}$ & $7(3.8)$ & $2(10)$ \\
\hline Anti-HBc IgM & $8(4.4)$ & $0(0.0)$ \\
\hline
\end{tabular}

\section{Discussion}

The present study was conducted for detection of Occult Hepatitis B (OHB) in blood donors in Diyala province using ELISA test. In present study, $\mathrm{HBs} \mathrm{Ag}$ was detected in (4.5\%)of blood donors, while when tested the negative blood donors for HBs Ag by anti-HBc IgM using ELISA test (4\%) were positive. So the result of this study shows the need to include anti-HBc IgM in routine screening of blood donors in blood banks in Iraq. The results in the present study were consistent with other Iraqi researcher reported $(4.3 \%$ and $5.1 \%){ }^{(10,13) \text { of }}$ HBs Ag in donors using ELISA test.

The present results were agreement with other workers that the rate of HBs Ag for HBV among blood donors were $(3.6 \%, 2.8 \%$ and $1.3 \%)$ respectively ${ }^{(14,15, \text { and } 9)}$. The present results revealed that the rate of antiHBs in blood donors were $(10 \%)$, this result was consistent with other results reported by other researchers were $10.5 \%$ reported by Afsar, 2010 in Turkey ${ }^{(16)}, 15.2 \%$ reported in Nigeria by Margrat, O.J. et al. 2011 ${ }^{(2)}$ and $18.8 \%$ reported in Egypt by Hosny, B. and Rania, B. $2013^{(9)}$. This higher percentage of positive anti-HBs donors can be explained that these individuals may have recovered from previos infection but have persistent low level of HBV.

The present study consistent with results of post studies that showed the rate of anti-HBc IgM were (3.8\%) in Egypt ${ }^{(9)}$, while were lower in study reported in Lobnan $(3.7 \%)^{(17)}$ And in Iraq were $(3.2 \%)^{(10)}$. In this study demonstrated positive rate anti-HBc IgM and anti-HBs among blood donorswere negative $(4.1 \%, 9.4 \%)$ for $\mathrm{HBs} \mathrm{Ag}$, this results consistent with other results were reported, since, Amadin, A.O, et al (2016) was detected (5.4\%) blood donors positive for anti-HBc $\operatorname{IgM}^{(5)}$. Other researchers were reported (3.4\%) in Iraq (10), $(5.1 \%)$ reported by Zahn, et al (2008) in Iran ${ }^{(18)}$. The detection of HBs Ag using ELISA may inaccurate and the proof of this is found in current study $4.1 \%$ positive for anti-HBc IgM nevertheless being negative to 
examine the HBs Ag and the reason is duo to the concentration of the virus in blood or that the investigation of HBs Ag was conducted in the window period, which cannot be determine the HBs Ag of the virus, which runs from 6 to 10 weeks, Or the use of different origin of laboratory kits that gives different sensitivity which affects on the results.

For that reason, we recommend the introduction of screening investigation of anti-HBc $\operatorname{IgM}$ of the HBV using ELISA within tests for blood donors as well as checking the investigation of HBs Ag it is the anti$\mathrm{HBc} \operatorname{IgM}$ first antibodies specific that appear after exposure to acute infection and even during window period and decreases concentration after 6 months, but it can be identified again during infection recovery ${ }^{(5)}$.

\section{References}

[1]. Cohen, S. (2007). Acute viral hepatitis. The Merck manual online Medical Labrary.

[2]. Margaret, O.J.; Olufisayo, A.A.; Emmanuel, D. and Moses, O.A. (2011). Hepatitis B core IgM antibody (anti-HBcIgM) among hepatitis B surface antigen (HBsAg) negative blood donors in Nigeria. Virol J. 8:513.

[3]. Lavanchy, D. (2004). Hepatitis B virus epidemiology, disease burden, treatment and current and emerging prevention and control measures. J. Viral Hepat. 11: 97-107.

[4]. Sorrell, M.F.; Belongla, E.A.; Costa, J. and et al. (2009). National institutes of health consensus development conference statment management of hepatitis B. Ann. Intern Med. 150: 104-109.

[5]. Amadin, A.O.; Adesola, O. O.; Lateef, S. and et al. (2016). Occult Hepatitis B virus infection in previously screened, blood donors in Ile-Ife, Nigeria: implications for blood transfusion and stem cell transplantation. Virology Journal. 13: 76.

[6]. Brooks, S., Ghosh, D., Mathur, P. 2007.Herpesviruses, cytomegalovirus. In:Medical microbiology. 24th edn.McGraw Hill, New York. Pp. 501-33.

[7]. Salawu, L.; Adegoke, A.; Abdoderin, A. and Huraina, H. (2011). Hepatitis B viral markers in surface antigen negative blood donors: the need to look beyond antibody negativity. West Afr. J. Med. 30(4): 292-5.

[8]. Nna, E.; Mbamalu, C. and Ekejindu, I. (2014). Occult HBV infection among blood donors in South-Eastern Nigeria. Pathog. Glod. Health. 4:204-144.

[9]. Hosny, B. and Rania, B. (2013). Anti-HBc and HBV-DNA detection in blood donors negative for hepatitis B virus surface antigen. American Journal od Molecular Biology. 3: 62-66.

[10]. Ibtihal, H.M. (2012). Detection of Occult hepatitis B virus infection by polymerase chain reaction in Diyala province. M.Sc. thesis. Collage of Education for Pure Science / Diyala University.

[11]. Oluyinka, O.; Tong, H.; Bui, T. and et al. (2015). Occult HBV infection in Nigeria blood donors and HBV transmission risk. Plos One. 10(7).

[12]. Seo, D.; Whang, D.; Song, E. and Han, K. (2015). Occult Hepatitis B virus infection and blood transfusion. World J. Hepatol. 7(3): 600-6.

[13]. Husan, A.Sh. and Omer, A. (2006). Prevalence and risk factors associate with blood transmitted viruses among cancer patients. Iraqi J. of community medicine Vol. 18 (1).

[14]. Ankra-Badu, G.A.; Malik, A.; Saleh, S. and Layala, B. (2001). Demographic characteristics of seropositive donors in Al-khabar. Annals of Saudia Medicine.; 21:1-2.

[15]. Geraldine, K.; Adel, A.; Jameel, N. and Said, H. (2006). Evidence of Occult Hepatitis B virus infection among Oman blood donors. A Preliminary Study. Med. Princ Parct. 15: 368-372.

[16]. Afsar, I.; Gungor, S.; Sener, A.G. and Yurtsever, S.G. (2010). The prevalence of HBV, HCV and HIV infections among blood donors in Izmir, Turkey. Indian Journal of Medical Microbiology. 26(3):288-289.

[17]. Ramia, S.; Ramlawi, F.; Kanaan, M.; Klayme, S. and Naman, R. (2005). Frequency and significance of antibodies against hepatitis $\mathrm{B}$ core (anti-HBc) antigen as the only serological markers for HBV infection in Lebnaese blood donors. Epidemiol. Infect. 133: 695-699.

[18]. Zahn, A.; Li, C.; Danso, K. and et al. (2008). Molecular characterization of OHBV in genotype E-infected subjects. J. Gen. Virol. 89(2): 409-418. 